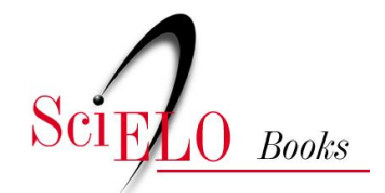

\title{
Overview of european activities in biotechnology
}

\author{
Karl Simpson
}

SIMPSON, K. Overview of european activities in biotechnology. In SORJ, B., CANTLEY, M., and SIMPSON, K., eds. Biotechnology in Europe and Latin America: prospects for co-operation [online]. Rio de Janeiro: Centro Edelstein de Pesquisas Sociais, 2010. pp. 21-28. ISBN: 978-85-7582-036-6.

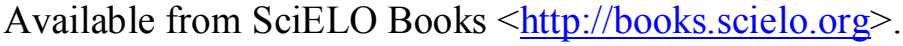

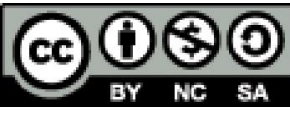

All the contents of this chapter, except where otherwise noted, is licensed under a Creative Commons Attribution-Non Commercial-ShareAlike 3.0 Unported.

Todo o conteúdo deste capítulo, exceto quando houver ressalva, é publicado sob a licença Creative Commons Atribuição Uso Não Comercial - Partilha nos Mesmos Termos 3.0 Não adaptada.

Todo el contenido de este capítulo, excepto donde se indique lo contrario, está bajo licencia de la licencia Creative Commons Reconocimento-NoComercial-CompartirIgual 3.0 Unported. 
European administrations and industrial organisations have realised that they cannot afford to miss out on the exploitation of biotechnology. European scientists working in industrial and university laboratories have made decisive contributions to the methodology of this 'New Biotechnology'. The first University Chair in biotechnology was established in Lyngby, Denmark in 1905 and the world enzymes market is dominated by two European companies; Novo, Denmark and GistBrocades, Netherlands.

Although total European industrial spending on biotechnology is approaching that of the USA, it is in the USA and increasingly Japan, that new commercial opportunities are being exploited. The funding of new ventures has been far more difficult in Europe. The USA offers important tax concessions for new ventures and there is ready availability of seedcorn and venture capital. Perhaps most importantly the USA has an entrepreneurial tradition that respects the risk taker.

The most important disadvantages facing Europe are those of internal language and trade barriers. Despite the activities of the European Commission there are still separate markets in the European Community, with different regulatory practices, legislatures and languages. rDNA regulations vary widely in the community. In Denmark draconian legislation is driving R\&D out of the country to more hospitable locations. The same may soon happen in Germany where a strong, but uninformed Green movement has considerable influence. Surveys have revealed that opposition to rDNA is most deeply rooted where the public perceives itself to be uninformed.

The harmonisation of Community regulations, aimed at creating a single market ready for January 1st 1993, is expected to improve this state of affairs, although much work will have to be done. The European Community has adopted a number of research and training programmes to stimulate and strengthen biotechnology in Europe. Proposals from the Commission from the mid-1970s were finally adopted by the Member States in 1981, launching the Biomolecular Engineering Programme, SEP': 15 MECU, 1982-86. This addressed specific bottlenecks, applying the results of 
modern genetics and enzymology in the agro-food sector. The larger Biotechnology Action Programme, 'BAP': 75 MECU, 1985-89, embraced a wider range of biotechnology topics, including topics of interest to a wider range of industries, an expanded safety programme, and projects on 'infrastructure' to strengthen cell- and micro-organism collections and databanks. At the time of going to press, a 100 MECU programme, Biotechnology Research and Innovation for Development and Growth in Europe, 'BRIDGE', 1990-94 is before Council and Parliament.

In addition to the research and training programmes, the Commission has recognised since 1983 the value of a coherent strategy for biotechnology, embracing not only the programmes mentioned above, but five other action priorities:

- new regimes for sugar and starch, to make these raw materials available at a competitive price to Community industry;

- new regulations, to provide in the context of the developing Common Market a common regulatory framework for biotechnology and its products;

- new regulations for the protection of intellectual property (patents and plant varieties), to ensure in the field of biotechnology clarity of legislation and adequate protection to maintain the incentive for research and innovation;

- demonstration projects, to stimulate the transfer of new technology towards commercialisation, in particular across the intersectoral and inter-disciplinary boundaries between science, industry and agriculture. The $80 \mathrm{MECU}$ European Collaborative Linkage of Agriculture and Industry through Research, 'ECLAIR', was a result launched in 1989;

- a 'concertation' action, for monitoring and awareness of emerging opportunities and challenges, and in order to improve co-ordination in biotechnology relevant policies between the several Commission services involved, and between Community and Member States. With the strong support of the European Parliament, this multidimensional response enabled the Commission to develop an integrated response to the challenges of biotechnology.
One of the most desirable consequences of Community and National activities in biotechnology has been the move to enhance communication between nations, industry, universities and ministries. Inter-national consultation has been a feature of newly established biotechnology programmes such as those of Greece and Spain.

\section{The European Biotechnology Industry}

In the USA the biotechnology industry is dominated by small high tech companies with few products, brought into existence with venture funding. In Europe medium to large companies with a long established pedigree and a diverse range of products from fertilisers to DNA probes are dominant. Until very recently only in the UK, and to a much lesser extent the Netherlands, has venture capital allowed the emergence of significant numbers of small to medium US style ventures. In 1988 and 1989 new venture capital companies are seeking business in all parts of the community. Significantly there is some real seed corn capital available.

All of Europe's traditional chemical and pharmaceutical giants have now invested heavily in rDNA technology, adding it to their mainstream programmes in the health care and agriculture sectors. University/Industry partnerships have played a major rle in transfer-ring the appropriate technologies. In the UK this is typified by the ICI/University of Leicester relationship. Leicester, where Alec Jeffreys invented DNA fingerprinting, is one of Europe's leading centres of rDNA research. In W Germany Hoechst (still in disfavour with the government after its decision to invest in Massachusetts General Hospital) has a number of collaborative ventures with university laboratories.

\section{What Are Europe's Strengths?}

The fragmentation of Europe has paradoxically provided a major asset. Firms have grown up in an environment that requires export earnings. Knowledge of export regulations and a lack of dependence upon internal markets are in sharp contrast to many US firms who have the world's largest single market at their doorstep. The old colonial powers of Europe have left their languages as a permanent monument to occupation. Language thus provides privileged access to markets such as Latin America and Africa. 
Several areas of biotechnology are dominated by European science or companies including: enzyme production, agro-biotechnology, biosensors, waste treatment and speciality chemicals.

European firms are generally willing to contemplate participation in joint ventures, both within and outside the Community. There is some apprehension about the loss of European proprietary knowledge to the USA and Japan through mismanagement of joint venture activity.

\section{A Summary of National Activities in the EEC}

BELGIUM

The governments of the Flemish and French speaking areas have both implemented support programmes for biotechnology. Large companies Solvay and Smith Kline Rit have moved firmly into biotech. Small companies including Plant Genetic Systems and Phytotec, with good university contacts are making rapid progress to success internationally.

\section{DENMARK}

Despite a tough attitude to biotech legislation, the government has committed another US\$60 million in the next four years. A small country, but strong in enzymes and gene technology. Novo has been active in protein engineering and European collaboration. Rationalisation in the domestic biotechnology industry is exemplified by the merger of Novo and Nordisk, both major insulin producers with rDNA technology.

FRANCE

In 1987 the conservative government overturned spending committed by the departed socialists, but the biotechnology Mobilisation Programme continued in weakened form. May 1988 saw the Socialists return under Rocard, and Minister Curien almost immediately instituted massive new investment in biotechnology. France has major strengths in bioreactors centred on Daniel Thomas in the University of Compiègne. Agro biotechnology is another strong field, Limagrain has developed artificial seeds and Moet-Hennessy is looking at the micropropagation of woody plants. Club Agri has a 4 year, US\$3 million programme of club sponsored research.

Sanofi, an Elf Aquitaine subsidiary with major health-care biotech commitments had turnover of more than US\$600 million last year.
Transgène, the rDNA and cell biology firm works in collaboration with several major French companies and is starting to be a candidate for entry into the international league.

\section{FEDERAL REPUBLIC OF GERMANY}

One of Europe's biggest biotech spenders. Major public expenditure by both central (US\$700 million over 5 years in latest programme) and regional governments. Central government is being forced by Green movement to enact restrictive legislation. Some companies may look elsewhere for new R\&D activity. Biotechnology Centre in Braunschweig is world class for fermentation development and general biotech activity. Companies such as Hoechst, Bayer, BASF have bought in all the new skills, but are very secretive about R\&D. Hoechst is far advanced in yeast expression systems, but information about future products is mostly rumour. BASF is the latest giant to earn government disapproval as it sites its major molecular biology facility in the USA. The Bissendorf Biotechnology Group have come from nowhere to being an exciting group of companies with international connections and major investments. Venture capital is opening up and a number of new firms are taking off. Middle sized companies such as Biotest have gone public to fund new biotech activities.

GREECE

Not really a biotech power, but the Institute for Molecular Biology and Biotechnology, Heraklion, is a major new institute devoted to keeping Greece in the picture. Vioryl is important in flavours, pheromones and plant tissue culture. Biohellas is first biotech company to exploit new legislation to create high tech enterprises. Old pharmaceutical companies such as PN Gerolymatos are entering the area of biotechnology.

\section{REPUBLIC OF IRELAND}

Weak economy undermines the very strong university system which offers top class skills. Small biotech companies have arisen to exploit Ireland's Import Substitution Programme. Guinness has major bio-tech investment with top class rDNA facilities and skills in yeast biotech. The Agricultural Institute in Dublin funds animal and plant biotech studies. Several companies such as Biocon, Nochtec, are having success in exports. 
ITALY

Has come rather late into the arena, but is putting money into a major national initiative to support industry in a range of mission-orientated projects. The government has talked of an Italian Human Genome project. Major companies are in acquisition moods and have got hold of biotech skills. Farmitalia, Ferruzzi and the ENI group (including Sclavo) are leading firms. Major academic industrial collaboration is being encouraged.

\section{THE NETHERLANDS}

Small country, but host to several multinationals. Biotechnology is of great importance with $7 \%$ of world turnover. The government restructured biology six years ago and most university research is now partly industry sponsored. After uncomfortable start, applied research is stronger in Netherlands than anywhere else in Europe. National skills include enzymes, yeast, dairy biotech, protein engineering. Major companies include: Unilever, Philips, Shell, Akzo, Gist-Brocades. Many small companies are university or institute based and enjoy good relations with big brothers. Government encourages foreign biotech investment.

\section{PORTUGAL}

Newly arrived in the EEC, Portugal has little biotech. A national Biotechnology Centre is now proposed. Companies include: Cipan (antibiotics) and Franco-Farmaceutica (immunology, vaccines). The 21 renowned Gulbenkian foundation is not interested in commercial spin off operations.

\section{SPAIN}

Spain until recently had no significant biotechnology industry, although it has first class university facilities. A major Mobilisation Programme is intended to put Spain on the biotech map. Built at a cost of US\$3 million the new Biotechnology Centre with a British head, Dr Michael Parkhouse, will house more than 100 scientists. Biotechnology active companies include: Atom, Laboratoris Girfols, Laboratoris Knickerbocker and Processos Enzimaticos. University/ industry collaboration is in its infancy.

\section{UNITED KINGDOM}

Government spending in biotech is lower than that of Germany, but UK has arguably the most healthy biotech industry in Europe. UK firms pioneered access to venture capital, about half European venture funding in biotech is British (although as much as $70 \%$ is invested in USA). Despite cut-backs in fundamental research, applied research is receiving support from the biotech programmes of several ministries. Giants like ICI, Unilever, as well as smaller firms work with university departments.

Celltech is now in profit situation as world's largest monoclonals producer. It will be the first British start up to make the transition from small high tech to tomorrow's new style middle size pharmaceutical firm. Although overall spending is limited the UK actually has competence in a wider range of biotech activities than the USA. Strong points include biosensors and protein engineering, PE. The Inmos transputers are being assembled in parallel to give enormous real time power for PE applications in the hands of companies like British Biotechnology, which in addition is perhaps the only firm to offer routine gene synthesis. The UK has pioneered the application of the 'club' concept for industry-university collaboration. 